\title{
The Successes and Failures of the Interventions of the European Union, the African Union and Neighbouring Powers in Somalia
}

\author{
Isabel K. Düsterhöft and Antonia I. Gerlach*
}

\begin{abstract}
Somalia has been subject to numerous interventions since the failed UN-led mission in 1992. Both the international community, embodied by regional organisations such as the European Union and the African Union, and other neighbouring powers have attempted to stabilise the Horn of Africa. This paper analyses a selection of interventions and involvements and assesses their successes and failures in view of improving Somalia's dire condition. In doing so, this article argues that regional approaches must be comprehensive and aimed at Somalia's core illness, the security and political vacuum, while international involvement should be aimed at combatting the superficial symptoms, piracy and terrorism.
\end{abstract}

Keywords: Somalia, Horn of Africa, Intervention, ATALANTA, AMISOM

Somalia, Horn von Afrika, Intervention, ATALANTA, AMISOM

\section{Introduction}

S omalia has been a centre of crises, (armed) conflicts and lawlessness for decades, and more precisely since the overthrow of dictator Siad Barre in 1991. The dire situation of the Somali population can only be comprehended in view of the country's historical and political particularities, which will be outlined briefly in the following.

The area of today's Somalia is an artificial construct, with arbitrary borders taken over from a disastrous period of colonisation. There have been both attempts of irredentism ("Greater Somalia") and secession efforts, which have never been internationally recognised but essentially partitioned the country into three regions (the semi-autonomous state of Puntland in the North-East, the de facto independent Somaliland in the North-West, and South and Central Somalia, practically governed by warlords and clan militia $\left.{ }^{1}\right)$. These brought about disputes over land and resources, which have never been settled and have contributed to the incapacity of Somalis to create a sense of community, unity, or at least peaceful co-existence. ${ }^{2}$

Additionally, the area is plagued by continuous draughts, which led to disastrous humanitarian crises and the failed attempt of the first ever humanitarian intervention by the UN in the early 1990s (UNITAF and UNOSOM I+II); ${ }^{3}$ Somalia has since been struggling to create a functioning state apparatus, having been ruled by warlords, clans and paramilitary groups. The country is prone to terrorist attacks and control, the most important one allegedly being al-Shabaab, a radical spin-off of the UIC (Union of Islamic Courts). Al-Shabaab is reportedly still influencing if not controlling most parts of Somalia and is

* Isabel Düsterhöft (LL.M.) and Antonia Gerlach (B.A.) are candidates for the M.A. Peace and Security (2013) at the Institute of Peace Research and Security Policy at the University of Hamburg.

1 Jaeger, Raphaël, "Country Profile Somalia," The Fund for Peace Country Profiles, (Washington: 2012) 3.

2 It is also important to note that Somalia is a clan-based society.

3 See Lewis, Ioan and Mayall, James, "Somalia," in Berdal, Mats and Economides, Spyros (eds.), United Nations Interventionism 1991-2004, (Cambridge: Cambridge University Press, 2007) 108-138. classified as a terrorist group with purported ties to Al Qaeda. ${ }^{4}$ In view of these particularities, Somalia led the list of the Failed States Index in 2012. ${ }^{5}$

In the following, the international and regional involvement in Somalia will be analysed on the basis of selected recent and current (military) interventions and participations, aimed at improving Somalia's situation.

\section{The European Union in Somalia - NAVFOR ATALANTA}

\subsection{Reasons for Intervention}

Alongside terrorism and starvation, piracy is one of the biggest security concerns of the international community in relation to Somalia. ${ }^{6}$ Although the first documented cases of piracy took place as early as 1989,7 this phenomenon developed from a rather marginal one to a well-structured and -organised 'criminal activity' that has experienced a drastic increase since $2008 .^{8}$ It is widely acknowledged that piracy is a consequence of the problems on land, which include two decades of war, extreme poverty, high numbers of refugees and internally displaced persons, humanitarian catastrophes, rise of terrorist networks, as well as a prevalent security vacuum. ${ }^{9}$ Thus, piracy is only a small part of the overall problem of Somalia, but has

4 Human Rights Watch, Harsh War, Harsh Peace: Abuses by al-Shabaab, the Transitional Federal Government, and AMISOM in Somalia, (New York: Human Rights Watch, April 2010) 17.

5 Consult http://www.fundforpeace.org/global/?q=fsi.

6 Ehrhart, Hans-Georg and Petretto, Kerstin, "Somalia: 'gescheiterter Staat' als Arena für Machtverschiebungen," in HSFK, BICC, FEST, IFSH, Friedensgutachten 2012, (Berlin: LIT Verlag Dr. W. Hopf, 2012) 182

7 Maouche, Alexandre, "Piracy along the Horn of Africa: An Analysis of the Phenomenon within Somalia," PiraT-Arbeitspapiere zur Maritimen Sicherheit 6, (2011) 18; Petretto, Kerstin, "Somalia und Piraterie: keine Lösung in Sicht, weder zu Wasser noch zu Land," Hamburger Informationen zur Friedensforschung und Sicherheitspolitik 49, (2010) 5.

8 Maouche, 6-7.

9 Petretto, 3. 
gained international attention and led to the involvement of various actors, including the EU. ${ }^{10}$

\subsection{Actors and Mandate}

Due to the rising number of piracy attacks, which have extended from the Gulf of Aden and the Somali basin to maritime regions closer to India and South Africa, and allegations that the Puntland authorities are involved in acts of piracy (and terrorism), ${ }^{11}$ the EU has recognised the central role that this phenomenon plays in destabilising Somalia. In December 2008 it launched its NAVFOR (Naval Force) mission ATALANTA ${ }^{12}$ as the first of this type in the framework of the European Common Security and Defence Policy. The operation is currently extended until December 2014 and is supported by numerous European nations, employing around 1,500 military personnel including those based on land. ${ }^{13}$ The area guarded is $2,000,000$ square nautical miles $(4,000,000$ square $\mathrm{km}$ ) and extends from south of the Red Sea to the Gulf of Aden, to the Western part of the Indian Ocean and to Somali coastal territory. The budget for 2012 is projected at 8.3 million Euros.

The mandate of ATALANTA developed in various steps. It was initially (2007/08) constituted by France, Denmark, the Netherlands and two NATO ships providing protection to WFP (World Food Programme) ships delivering humanitarian aid. Ever since the request by the Somali TFG (Transitional Federal Government, 2004-2012) and the UNSC (Security Council) Resolutions in 2008 (1816 and 1846) ${ }^{14}$ the mandate has continuously expanded and currently reads as follows:

- "The protection of vessels of the World Food Programme (WFP) delivering food aid to displaced persons in Somalia; the protection of African Union Mission in Somalia (AMISOM) shipping;

- The deterrence, prevention and repression of acts of piracy and armed robbery off the Somali coast;

- The protection of vulnerable shipping off the Somali coast on a case by case basis;

- In addition, EU NAVFOR - ATALANTA shall also contribute to the monitoring of fishing activities off the coast of Somalia". ${ }^{15}$

It is further aimed at creating an international transit corridor in the Gulf of Aden to allow military ships to effectively

10 It is noteworthy that the region of Somaliland has tackled the problem of piracy at a much earlier stage already and that this problem is nowadays basically inexistent in this region.

Operations and missions in relation to piracy include NATO Operation Ocean Shield, the United States-led Combined Task Force, the EUNAVFOR ATALANTA Operation and the individual involvement of countries such as China, India, Japan, Russia, Iran, Thailand, etc.

11 Munson, Mark B., "Somalia: Is There a Way Forward: the international community continues to treat symptoms - piracy and nascent terrorism rather than anarchy, the country's underlying disease," Proceedings / U.S. Naval Institute 137, (2011) 53.

12 Consult http://www.eunavfor.eu for more information.

13 Participating countries include: Belgium, France, Germany, Greece, Italy, Luxembourg, the Netherlands, Spain and Sweden.

14 United Nations Security Council, Resolution 1816, 5902 $2^{\text {nd }}$ meeting on 2 June 2008 and Resolution 1846, 6026 ${ }^{\text {th }}$ meeting on 2 December 2008.

15 See also Council of the European Union, Council Joint Action 2008/749/CFSP Brussels 19 September 2008; Council Joint Action 2008/851/CFSP, Brussels, 10 November 2008 and Council Decision 2010/766/CFSP, Brussels, 7 December 2010 , for details on how the mandated was amended. defend and accompany slow-moving vessels. ${ }^{16}$ The EU has also supported the setting up of a Maritime Security Centre at the Horn of Africa (MSCHOA), a local office of the UK Maritime Trade Operation (UKMTO) in Dubai, the signing of the Djibouti Agreement (2008), ${ }^{17}$ and the training of Somali security personnel in Uganda, Ethiopia, and Djibouti, allowing for increasing regional coordination of counterpiracy strategies. ATALANTA is merely one component of the EU's comprehensive approach to piracy ${ }^{18}$ and only tackles a small part of the country's comprehensive problem.

\subsection{Successes and Failures}

According to official statements made by the EU Foreign Affairs Council, ATALANTA is a success, as it contributes to deterring, preventing, and disrupting pirates' activities. ${ }^{19}$ In fact, not a single WFP vessel has been attacked by pirates since the beginning of the mission. Furthermore, as statistics show, the success rates of piracy have decreased drastically. ${ }^{20}$ Nevertheless, this neither indicates that the humanitarian situation in Somalia has improved nor that the overall number of actual and attempted attacks has diminished. Instead, new trends have taken the centre stage, such as the shifting of the geographical range, the increased connections with al-Shabaab, and the growing use of lethal force and hostage-taking. ${ }^{21}$ Thus, even though success rates of attacking ships have gone down, ATALANTA has not been capable of deterring attempted piracy attacks in general. Furthermore, despite Somalia's claim that the international illegal fishing activities and the dumping of toxic waste in Somali waters have been catalysts for piracy, ATALANTA has barely engaged in monitoring fishing activities let alone in reducing this problem. ${ }^{22}$

General criticism is targeted at the fact that this mission is solely focused on activities at sea and at the insufficient efforts to combat the roots of the problem ashore, such as efforts in humanitarian and development aid, support in peace processes, and state-building. Additionally, it appears that ATALANTA's mandate in no way comprises those who are behind this type of (organised) crime and hence does not successfully address the aspects of funding, as well as neglects the diaspora's involvement in piracy. In this respect, it is also not part of the mission's mandate to tackle the connections of piracy and terrorism and to find parallel solutions to these inter-linked phenomena.

Despite this criticism, it appears that the current mandate of ATALANTA is too vast, which decreases the mission's

16 Petretto, 6.

17 This concerns a peace accord between the Alliance for the Re-liberation of Somalia and the TFG.

18 The EU also conducts a training mission in Somalia; read more on the EU's comprehensive approach at http://consilium.europa.eu/eeas/securitydefence/eu-operations/eunavfor-somalia.aspx?lang=en.

$193023^{\text {rd }}$ Foreign Policy Council, Council Conclusions on Piracy off the Coast of Somalia (14 June 2010) 1.

20 Consult the EU Naval Force Piracy Statistics of e.g. 31 December 2012 at http://www.eunavfor.eu/press-2/downloads/20121231_ eunavforpiracystatistics_eu-u/.

21 Ehrhart, Hans-Georg and Petretto, Kerstin, "The EU and Somalia; CounterPiracy and the Question of a Comprehensive Approach," Study for The Greens/ European Free Alliance, (2012) 33-36.

22 Ibid., 35-36. 
capabilities and flexibility. It may be worth considering transferring the relatively 'easy' task of accompanying WFP ships to other actors and to increasingly focus on the effective combating of terrorism with a view towards a sustainable solution. This must include the halting of fishing and dumping of toxic waste in Somali waters. It must further be supported by complementary missions aimed at establishing alternative sources of income on land, ${ }^{23}$ identifying those who finance and motivate piracy in the dark and creating capable national, regional and international justice systems, which are equipped and prepared to deal with cases of piracy. ${ }^{24}$ Overall, it must be kept in mind that an effective and lasting solution to the problem of piracy can only be found with the involvement of the Somali population and those that resort to acts of piracy. The following section examines the question of how far the involvement of the AU (African Union) has been effective in targeting the issues on land.

\section{The African Union in Somalia - AMISOM}

\subsection{Reasons for Intervention}

The origins of the AMISOM mission (African Union Mission to Somalia) lie in the failed attempt of the IGAD (InterGovernmental Authority for Development) in deploying a peace operation to Somalia in 2005, initiated by Ethiopia. Even though the AU's PSC (Peace and Security Council) authorised the deployment, the mission fell through when the UNSC refused to grant an exemption to the arms embargo imposed against Somalia. ${ }^{25}$ Furthermore, the UIC, as the de facto authorities in Mogadishu, opposed what they declared an Ethiopian invasion disguised under the pretext of a peacekeeping mission.

Despite the relative peace and security established by the UIC in Mogadishu, Ethiopian troops entered the region of Baidoa in December 2006 in order to support the TFG authorities the internationally recognised transitional regime at the time, yet in the eyes of many Somalis an Ethiopian venture of imperiously installing an illegitimate authority. ${ }^{26}$ After the outbreak of atrocious fighting between the UIC and Ethiopian forces, the PSC reintroduced their proposition of a peacekeeping force. In light of the violence, the UNSC endorsed Resolution 1744 on 20 February 2007, creating AMISOM. $^{27}$

23 This is especially important with regard to the fact that al-Shabaab has been functioning as an alternative provider of income, education, justice, social stability, food, etc., when the TFG was unable to do so.

24 Trial transfer agreements have been made with Mauritius, Seychelles and Kenya (currently negotiating with Tanzania), next to countries that have taken on selected cases, such as Germany.

25 Williams, Paul, "Into the Mogadishu Maelstrom: The AU Mission in Somalia," International Peacekeeping 16(4), (2009) 515.

26 Ibid., 517; see section 3.1. of this article.

27 Wagner, Jürgen, "AMISOM in Somalia," Informationsstelle Militarisierung (IMI) Magazin, (2007) 11; United Nations Security Council, Resolution 1744, $5633^{\text {rd }}$ meeting on 20 February 2007.

\subsection{Actors and Mandate}

The mandate of the UNSC envisaged the deployment of up to 8,000 forces to "provide support to the TFIs (Transitional Federal Institutions) in their efforts towards the stabilisation of the situation in the country and the furtherance of dialogue and reconciliation; [to] facilitate the provision of humanitarian assistance; and [to] create conducive conditions for long-term stabilisation, reconstruction and development".$^{28}$

The structure of AMISOM aimed at the creation of a modern, multidimensional peace support group. In this function, Burundi and Uganda first deployed approximately 6,100 military personnel, accompanied by a relatively small police component with officers from Burundi, Ghana, Nigeria, Sierra Leone, Uganda, and Zambia. The humanitarian side of the mandate was restrained to solely ensuring the delivery of services carried out by other stakeholders. In addition, AMISOM was supported by a reasonably large number of civilian personnel, which marked a change to previous AU peacekeeping missions. ${ }^{29}$ The overall costs of the mission amounted to roughly 250 million US Dollars per year; ${ }^{30}$ a large sponsor is inter alia the EU. ${ }^{31}$

\subsection{Successes and Failures}

AMISOM was not the first peace mission deployed by the $\mathrm{AU}$, yet it is the largest to date. The first 30 months were particularly challenging for the troops. They had been sent into what can only be described an active warzone; the peacekeeping mission had to work in an environment, where there was no peace to keep. ${ }^{32}$ This not only led to the danger of having to operate in such hard-fought territory, but it also put the AMISOM operation at risk to be seen as partisan. As a result, AMISOM was being heavily attacked, above all by the militant al-Shabaab group. ${ }^{33}$

This unrewarding task was topped by a severe lack of capacity and equipment. Just over 60 per cent of the authorised troops could be made available immediately; NATO supported the operation through airlifts to the respective areas; and only one year after the official start, AMISOM was being provided with much needed equipment worth US\$ 7 million from the UNMEE mission (Ethiopia-Eritrea). ${ }^{34}$ This not only hindered the execution of the operation, but also increased its negative perception within Somalia.

Furthermore, the heavy involvement of Ethiopian troops intensified the adverse image of AMISOM among the Somali people. After the coming to light of allegations of grave violations of international humanitarian law by AMISOM

\footnotetext{
28 Cited in Kromah, Lamii, "The Role of AMISOM's Civilian Component," Conflict Trends 2, (2010) 21-27.

29 Ibid., 25

30 De Coning, Cedric, "The Evolution of Peace Operations in Africa: Trajectories and Trends," Journal of International Peacekeeping 15, (2010) 23

31 Murithi, Tim, "Inter-governmental Authority on Development on the Ground: Comparing Interventions in Sudan and Somalia," in African Security 2(2-3), (2009) 149.

32 Williams, 521.

33 Human Rights Watch, 17.

34 Williams, 519-520.
} 
troops and the TFG forces, Human Rights Watch criticised the AU for turning a "blind eye to their allies' abuses on the ground", which included for instance ostensible mortar strikes with high civilian casualties. ${ }^{35}$

Moreover, the failure of the AU to acquire sufficient troops and to encourage its member states to participate in the operation shed doubts on the capability to generally organise and carry out peace missions on the African continent. The Romani Prodi Report (2008) found a "growing anomalous and undesirable trend" in terms of providing support to peace missions and states: "In the final analysis, the $A U$ will only be able to respond to crises effectively if there is sufficient political and financial commitment of its own member states and, more generally, of the international community. [...] It is a recipe for failure. [...] It undermines the credibility of peacekeeping and weakens the organisation that is responsible". ${ }^{36}$ In the case of AMISOM, this reluctance of the member states and the therefrom resulting understaffing led to a physical limitation of the mission to parts of Mogadishu. ${ }^{37}$

The majority of these failures and deficiencies in the implementation of the mission and the mandate can be seen as results of teething problems. AMISOM and the AU as the implementing authority learned from their mistakes and the situation improved notably, reporting multiple achievements in due course. AMISOM troops were able to secure the most important humanitarian corridors in Mogadishu in order to ensure humanitarian assistance to the civilian population of the capital. ${ }^{38}$ This may seem trivial for a peacekeeping troop; however, one has to bear in mind the war-ravaged environment in which this under-resourced mission had to operate.

In general, the support and protection for Somali civilians was exceptional for a military operation. AMISOM's military medical services, for example, were expanded to become the only reliable source of medical care for the Mogadishu population. ${ }^{39}$ This marks one part of the rebuilding of infrastructure, which is strongly supported and also implemented by the AMISOM Civil Affairs Unit. Thus, the TFG was strengthened, began to deliver at least basic services to the civilian population in Mogadishu and rebuilt key ministries and institutions. ${ }^{40}$ In this sense, AMISOM is far more than a mere peacekeeping mission.

Even though AMISOM was able to secure the legitimisation of a new Somali Federal Government in August 2012, the mission's major concern remains its future. The AU had always intended to eventually hand over the mission to the UN, yet the Secretariat seems less than committed to this idea; the debate about a clear and workable exit strategy only sincerely emerged after the Djibouti-Agreement in 2008 and

35 Human Rights Watch, 5.

36 Report of the African Union - United Nations panel on modalities for support to African Union peacekeeping operations, UN doc, A/63/66-S/2008/813, 31 December 2008, paras. 11, 15, 16.

37 Kromah, 23.

38 Ibid., 27.

39 See Lotze, Walter and Kasumba, Yvonne, "AMISOM and the protection of civilians in Somalia," Somalia Trends, (2012) 17-24.

40 Kromah, 27. the following withdrawal of Ethiopian troops from Somalia, ${ }^{41}$ and remains without a solution until today. It therefore comes to no surprise that most African governments still consider the Somalia mission as "too dangerous, too costly and unlikely to succeed". ${ }^{42}$ The following section outlines the manner of involvement of other African states, especially Ethiopia, Eritrea and Kenya.

\section{Neighbouring Powers in Somalia}

\subsection{Ethiopia}

Ethiopia's main concern in relation to Somalia has been the country's link to Eritrea. Its involvement dates back to the Ogaden war (1977-1978), during which Ethiopia and Somalia struggled for regional supremacy. ${ }^{43}$ Ogaden is a region bordering the two countries, now part of the former, and is used as a buffer zone to absorb the high influx of Somali refugees, potentially destabilising the fragile ethnic balance in the country. ${ }^{44}$ In this regard, Ethiopia has primarily been interested in supporting the TFG in building a stable Somalia with a constitution and capable military. ${ }^{45}$ As mentioned previously, Ethiopia initially intervened in 2006, an engagement, which, in the eyes of the Somali population, lacked legitimacy and was considered unwelcome. This military involvement led to a relative strengthening of extremist forces, not least due to the counter-productive involvement of Eritrea as described below. The intervention stopped in 2009 and has widely been considered unsuccessful, not improving the country's situation but instead strengthening Somalia's division. ${ }^{46}$ This was partly caused by Ethiopia's own national concerns and interests and partly due to the perceived lack of legitimacy of the intervention. However, since then, Ethiopia has been successfully involved in the training of Somali military forces in Djibouti (2009) and Uganda (2010), and in the weakening of al-Shabaab in the context of the Kenyan Operation (2011). ${ }^{47}$

\subsection{Eritrea}

Eritrea's links to Somalia date back to its struggle for independence from Ethiopia in the 1980s, where Somalia played an essential role by granting passports to fighters of the Eritrean People's Liberation Front. ${ }^{48}$ With regard to the Ethiopia-Eritrea war (1998-2000), Eritrea's main goal remains to reduce Ethiopian influence in Somalia, rather than improving Somalia's condition. ${ }^{49}$ Since 2000, it has

41 Williams, 523; see the following section with regard to Ethiopia's involvement

42 Ibid., 525

43 Møller, Bjørn, "The Somali Conflict: The Role of External Actors," DIIS Report 3, (2009) 20

44 Ibid.; in comparison to Somalia, Ethiopia is a mainly Christian country.

45 Reuters, "Ethiopia says troops stay longer in Somalia," 23 June 2012 Somalia's new Constitution was passed in June 2012.

46 Møller, 21.

47 International Crisis Group, "The Kenyan Military Intervention in Somalia," Africa Report 184, (2012) 6.

48 Ibid.

49 Hansen, Stig Jarle, "The Enemy's Enemy: Eritrea's Involvement in Somalia," Jane's Intelligence Review 21, (2009) 30. 
been involved in a proxy war on Somali territory, allegedly ensuring financial and arms support to (Islamist) insurgent groups, for which it was (repeatedly) sanctioned by the UN. ${ }^{50}$ Although Eritrea has reportedly decreased its support for alShabaab, ${ }^{51}$ it allegedly continues to supply money and arms to insurgents. Hence, Eritrea's involvement is not focused on improving the situation in the Horn of Africa, but rather on preventing Ethiopia's rise as the strongest regional power. The involvement is clearly determined by national interests and the long established struggle between Eritrea and the country it seceded from. Thus, Eritrea's contribution is rather counterproductive to international and regional efforts and poses a real risk to long-term and sustainable solutions.

\subsection{Kenya}

Kenya's involvement in Somalia is mainly aimed at stabilising the overall region of the Horn of Africa. Its principal concerns are border security, growing numbers of refugees, the threat posed by al-Shabaab, and the decrease of trade and tourism in the region, especially with a view to al-Shabaab's (previous) control of Kismayo (Somalia) as a hub of profitable trade. ${ }^{52}$ The security vacuum in Somalia has direct effects on the bordering regions of Kenya and is considered a destabilising factor for the country. Hence, on 16 October 2011 Kenya launched Operation Linda Nchi ('Protect the Country'), deploying thousands of troops in Somalia's Juba Valley to wage a war on al-Shabaab. Its mandate was to train around 2,500 militiamen, to establish an administrative structure and to support other militia brigades. ${ }^{53}$ The military intervention was launched on the basis of Kenya's alleged right to selfdefence (Article 51 UN Charter), ${ }^{54}$ illustrating Kenya's deep concern for its own stability and safety. The operation has been criticised for being ill-equipped, for not having consulted the TFG, for the strategic challenges it encountered due to sub-optimal timing being launched in the rainy season, as well as for solely focusing on al-Shabaab and widely ignoring other pressing problems in Somalia. ${ }^{55}$ Nevertheless, Kenyan Defence Forces, which were formally integrated into AMISOM in July 2012, brought about the fall of the last city controlled by al-Shabaab, Kismayo, in September/October 2012. ${ }^{56}$ It yet remains to be seen whether al-Shabaab will recover, how the group will react to this event, and whether this may result in acts of retaliation. Overall, Kenya's involvement is certainly also motivated by national concerns, but is in comparison to Ethiopia's and Eritrea's participation the only semi-successful military operation, even though its successes are solely in

50 United Nations Security Council, SC/9833 "Security Council imposes sanctions on Eritrea over its role in Somalia. Refusal to withdraw troops following conflict with Djibouti," $6254^{\text {th }}$ meeting on 23 December 2009; SC/10471 "Security Council, by vote of 13 in favour, adopts resolution reinforcing sanctions. Regime against Eritrea 'calibrated' to halt all activities destabilizing region," 6674 $4^{\text {th }}$ meeting on 5 December 2011.

51 Inter alia: Aaron Maasho, "Eritrea Reduces Support for al-Shabaab: UN report," Reuters, 16 July 2012.

52 International Crisis Group, 10.

53 Ibid., i and 2.

54 United Nations, Charter of the United Nations, 24 October 1945, 1 UNTS XVI.

55 International Crisis Group, 2-6.

56 Inter alia: Ni Chonghaile, Clar, "Kenyan troops launch beach assault on Somali city of Kismayo," The Guardian, 28 September 2012; BBC, "Somali and African Union troops enter Kismayo," 1 October 2012. relation to terrorism. Other core problems are, yet again, neglected by this intervention.

Further countries that have, in one way or another, been involved in Somalia are Djibouti, Sudan, Uganda and Yemen. ${ }^{57}$ They have offered their territory for reconciliation talks, conferences, training of Somali national forces, and have been engaged in AMISOM's intervention. Yemen has allegedly been involved in the shipments of arms to the TFG and in the war on terror on the side of the United States.

While one would certainly argue that it should rather be up to African states, and more specifically neighbouring powers to act as peacekeepers in Somalia rather than remote Western armies, the above-described involvements have overall shown that such an approach similarly comes with difficulties. National interests and concerns are frequently motivations for intervening and the most important factors for shaping the type of involvement and its extent. Rivalry between neighbouring states is potentially detrimental, preventing them from honestly tackling the myriad of issues at their roots. Thus, regional involvement has mainly solely been aimed at specific issues, those of national interest, and has failed in targeting the actual root causes for Somalia's dire situation.

\section{Conclusions}

The various interventions and involvements evaluated above clearly illustrate that the international as well as regional community is not ignoring Somalia and its dire situation. However, they also clearly portray that the diverse actors have different interests and goals, impacting mandates, extent and execution of their participation.

The missions currently being undertaken in and around Somalia are by all means important and to an extent successfully fight the symptoms they are addressing. However, the two main features that are being tackled - piracy and terrorism - have their roots in the Somali political structure, or rather the nonexistence thereof, which is a problem that is internationally being more or less ignored. The current interventions are mainly addressing the superficial symptoms of an affliction that is grounded in the Somali anarchical disorder.

In order to defeat this state of lawlessness and to come to palpable results many steps are necessary. This includes not only the need for cooperation between the intervening foreign states and organisations, but also joint actions of the international community and Somali institutions. National interests need to be put aside in order to tackle the underlying problems in Somalia and to reach the goal of constructing a stable and strong institutional foundation of the Somali government by re-establishing the rule of law and national stability.

Overall, a possible future for interventions in Somalia might (have to) look differently. Instead of rigidly separating the diverse regional interventions (AMISOM and neighbouring powers), one might consider merging the different actors and approaches into one operation, aimed at a sole and clearly

57 Møller, 22-23. 
defined objective: to support the Federal Government in effectively stabilising the Somali state and reconstructing a functioning rule of law. By purposely involving the region and Somalia itself in the process of stabilising the Horn of Africa, the Somalis can re-build their country and re-grow from the inside instead of having to operate in an imposed administrative and authoritative structure. In this respect, it is crucial to pay due attention to the prevalent clan structure and radical forces in Somalia, including al-Shabaab. This might be the only way out of the internationalisation of the Somali crises, which has plagued the state at the Horn of Africa for decades and has not lead to a sustainable cure for the core illness of Somalia. Counterproductive involvement by states such as Eritrea, supremacy struggles, and national interests must be accounted for when involving regional powers side by side and must be kept to the minimum to allow for a sustainable solution focused on Somalia's wellbeing.

The role of European and other international forces should mainly be a supportive one. With their experience and expertise they can support Somali and regional forces in enabling regional ownership. Their main area of involvement, however, should remain the fight against the symptoms, terrorism and piracy, which they have been tackling rather successfully, also with the help of regional powers. This division between one coherent regional/local approach to the core problems and international help with regard to the symptoms will not only clearly define mandates, duties and activities, but it will also offer more specific and defined goals to the missions, resulting in a greater likelihood for success.
Additional recommendations include the involvement of the Arab League in the process of stabilising Somalia, as well as of countries bordering the maritime areas that are affected by Somali piracy and hence have a great interest in the stabilisation of the region. Furthermore, in any kind of consideration on how to amend the situation in Somalia, it is essential to pay due attention to the Somali diaspora living abroad. They play a key role within the context of both piracy and terrorism, not only as possible supporters of both criminal activities, but also as driving forces for a successful rebuilding and stabilisation of their country. Thus, the diaspora should be included in any kind of stabilisation process in Somalia.

The recent passing of a constitution in June 2012 and the swearing in of a new parliament and president in August and September 2012 have certainly been first steps towards such a development. It remains to be seen whether the new Federal Government will be able to successfully tackle the root causes of Somalia's instability and to what extent the Somali population will, after years of anarchy, allow the government to rule. Its achievements in catering basic needs related to food, income, social stability, justice, security, education, etc. will determine its own success in reconciling and reuniting the country. This will be especially interesting with regard to the regions of Somaliland and Puntland that are striving for more autonomy. In any case, honest and committed international as well as regional involvement will remain of great importance in guaranteeing Somalia's successful future.

\title{
Wo steht die Afrikanische Friedens- und Sicherheitsarchitektur? Bilanz und Herausforderungen
}

\author{
Judith Vorrath*
}

\begin{abstract}
When considering the areas of policy formulation, institution-building and actual peace-related activities, the African Peace and Security Architecture (APSA) has overall made substantial progress. Because of APSA's continuing strong external dependence, capacity-building remains necessary. However, it must balance the entire structure; furthermore, by itself it will not be sufficient to guarantee "African ownership". The future of APSA is not simply a question of money or the adequate implementation of projects, but it requires the involvement of civil society as well as a clear political and conceptual framework for "African" solutions. It is crucial for the AU under the new Commission Chairwoman to devise and focus on its own political approaches, a balanced institutional structure, and a strengthening of the multi-dimensional profile of its operations..
\end{abstract}

Keywords: African Union, peace, security, regional organization, peace-building

Afrikanische Union, Frieden, Sicherheit, Regionalorganisation, Peacebuilding

\section{Einleitung}

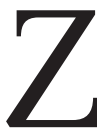
um Zeitpunkt der Gründung der Afrikanischen Union (AU) vor zehn Jahren schienen die Aussichten der Organisation, Frieden und Sicherheit auf dem Kontinent eigenständig und nachhaltig zu stärken, relativ gering. In einer Vielzahl von Mitgliedstaaten waren in den 1990er
Jahren innerstaatliche Konflikte ausgebrochen oder erneut eskaliert und legten die weitgehende Wirkungslosigkeit der Organisation für Afrikanische Einheit (Organisation of African Unity, OAU) als AU-Vorgängerin bei der Prävention, dem

\footnotetext{
Dr. Judith Vorrath ist Wissenschaftlerin in der Forschungsgruppe Sicherheitspolitik der Stiftung Wissenschaft und Politik (SWP), Berlin. Die Autorin dankt Claudia Simons für ihre Anregungen zu diesem Artikel, besonders zur Frage von "African ownership“.
} 